UDK 37.034:364.4-053.2

Prethodno saopštenje

Primljeno: 18.10 .2019 .

Revidirana verzija: 25.11.2019.

Odobreno za štampu: 26.11.2019.

DOI: https://doi.org/10.46630/gped.2.2019.06

\title{
PODSTICANJE MORALNOG RAZVOJA DECE ZAŠTIĆENE PORODIČNIM SMEŠTAJEM U HRANITELJSKIM PORODICAMA
}

\author{
Sanja Sretić ${ }^{1}$ \\ Centar za socijalni rad „Sveti Sava“ Niš \\ Univerzitet u Nišu, Filozofski fakultet, Departman za pedagogiju (student DAS)
}

\begin{abstract}
Apstrakt: U vreme usložnjenih interpersonalnih odnosa, tranzicionih kretanja, multikuturalnosti, pitanja i problemi moralnog razvoja dece i mladih su naročito aktualizovana jer dovode u pitanje postojeće društvene i moralne vrednosti, metode i postupke kojima su se te vrednosti usvajale. Ovo istraživanje realizovano je sa ciljem utvrđivanja vaspitnih faktora u hraniteljskim porodicama i moralnog razvoja dece na hraniteljstvu predadolescentnog i adolescentnog uzrasta. U radu je korišćena sistematska neeksperimentalna metoda. Rezultati istraživanja su pokazali da se i hranitelji i deca nalaze na konvencionalnom kasnom stadijumu moralnog razvoja. Dobijene korelacije pozitivnog smera na pojedinim stadijumima u ispitivanju povezanosti stadijuma moralnog rasuđivanja deteta koje je na hraniteljstvu sa stadijumom moralnog rasuđivanja hranitelja kao i dobijene korelacije pozitivnog i negatvnog smera prilikom utvrđivanja vaspitnih postupaka hranitelja u podsticanju moralnog razvoja dece na smeštaju pokazuju da ne postoji usklađenost i strukturisan vaspitni uticaj na polju podsticanja moralog razvoja dece u hraniteljskim porodicama već da je on uslovljen brojnim individalnim, porodičnim i sredinskim faktorima što svedoči u prilog velikoj heterogenosti mreže hraniteljskih porodica. Dobijeni rezultati istraživanja impliciraju potrebu za većom stručnom podrškom kako hraniteljskim porodicama tako i profesionalcima u podsticanju moralnog razvoja dece bez roditeljskog staranja.
\end{abstract}

Ključne reči: moralni razvoj, metoda podsticanja; deca bez roditeljskog staranja; hraniteljska porodica

\section{Teorijski pristup moralnom razvoju dece na predadolescentnom i adolescentnom razvojnom stadijumu}

Moral i moralnost esencijalno predstavljaju jednu od osnovnih karakterisitka društva i međuljudskih odnosa i važna su determinanta na osnovu koje se konstituiše kriterijum uočavanja razlike između onoga što se određuje kao pozitivno ili negativno, dobro ili loše i sl. (Antonijević, 2013). Osim što je društveni fenomen jer

\footnotetext{
${ }^{1}$ s.sretic-15797@filfak.ni.ac.rs
} 
predstavlja jedan od kohezionih faktora i vrednosnog sistema jednog društva, moral je i individualni fenomen jer u moralnim odnosima učestvuju pojedinci sa svojstvima svojih ličnosti, sistemom vrednosti kojima su ovladali, stavovima, uverenjima. Individualni moralni razvoj odnosi se na proces učenja i razumevanja morala, kao i razvijanje navika moralnog ponašanja od najranijeg uzrasta (Miočinović, 2004). Odvija se kroz uticaj različitih faktora (porodica, škola, vršnjaci, mas-mediji) koji se razlikuju po značaju i doprinosu koji imaju u procesu moralnog razvoja, a koje nazivamo i agensima socijalizacije. Procesom vaspitanja, norme i principi postaju vrednosti onog trenutka kada su za pojedinca postali mera kojoj on teži u sopstvenom ponašanju i to ne zbog neprijatnih posledica u slučaju njihovog nepoštovanja već zbog uverenja u njihovu posebnu ulogu u društvenom životu.

U osnovi moralnog razvoja leže različiti teorijski pristupi koji su inspirisali istraživanja triju komponenti moralnosti i to bihejvioralne, afektivne i kognitivne, tj. sadejstvo ove tri komponente i njihovu ulogu u moralnom razvoju (Jevtić, 2012). Tako se u okviru psihoanalitičke teorije apostrofira osećajna komponenta, tj. o moralnosti se govorilo kao o produktu superega čije su funkcije moralna savest, samokontrola i stvaranje ideala. Prva anksioznost, tj. strepnja, koju je Frojd nazvao objektivnom strepnjom, predstavlja preteču kasnije moralne strepnje. Dečiji super ego po shvatanjima psihoanalitičara formiran je po uzoru na roditeljski superego što omogućava transgeneracijsko prenošenje tradicije i vrednosti (Popović, Miočinović 1977).

Sa druge strane u kognitivno-razvojnom pristupu (Popović, 1977; Markov, 2010) naglasak se stavlja na kognitivne procese i razvoj morala se posmatra kao sled kvalitativno različitih stadijuma mišljenja. Kognitivni i socijalno-emocionalni razvoj smatraju neraskidivim, paralelnim vidovima strukturalnih informacija koji se formiraju tokom razvoja. Moralno mišljenje deteta određenog uzrasta ima paralelu svojstvenu logičkom mišljenju istog uzrasta, tj. svaki nivo moralnog mišljenja iziskuje novi konstrukt kognitivnih operacija, koje nisu bile uspostavljene na prethodnom nivou. Podjednako, svaki stadijum zavisi od prethodnog, kao i od intelektualnih sposobnosti osobe, iskustva i učenja pod uticajem porodice i socijalnog miljea.

Žan Pijaže kao jedan od izrazitih predstavnika ovog pristupa (Piaget, 1932, prema Popović, Moičinović, 2004) moral najpre sagledava kao kognitivni proces, a njegovu suštinu zasniva na osećanju obaveze da se poštuju pravila društvenog reda i osećanju pravde. Razvoj moralnog suđenja posmatra se kroz menjanje stavova prema pravilima igre uopšte. Fokusirajući se na uzrast dece koji je obuhvaćen našim uzorkom, Pijaže smatra da se kod adolescenata razvija autonomna moralnost čija je osnovna karakteristika recipročnost („,dobar znači biti pravedan“). Dolazi do postepenog udaljavanja od usredsređenosti na sebe ka povećanju zauzimanja sa tuđe tačke gledišta i razumevanju tuđih misli i osećanja. Interakcija sa društvenom sredinom se zasniva na uzajamnosti i uzvratnosti. Autonomija se razvija upravo sa uzvratnošću kada je obostrano poštovanje dovoljno jako da osoba oseća u sebi želju da sa drugima postupa kako bi želela da oni sa njom postupaju. Postepeno gubljenje egocentrične perspektive dovodi do povećane jednakosti i saradnje među vršnjacima, sagledavanja stvari sa tuđeg stanovišta i povećane brige za dobrobit i prava. 
Razvojni psiholog Kolberg kao Pijažeov sledbenik (Kohlberg, 1984) smatrao je da karakteristike, kvalitet i stepen moralnog rasuđivanja zavise od nivoa razvoja kognitivnih struktura, koje oblikuju manifestno ponašanje. Kognitivne strukture javljaju se u nepromenljivim, diskontinualnim stupnjevima razvoja, a međusobno su povezane univerzalnim stupnjevima razvoja kognicije. S tim u vezi moralno rasuđivanje razvija se sa početnog fokusiranja sa hedonističke i fizičke brige do prepoznavanja i identifikacije sa međuljudskim i društvenim očekivanjima do holističke perspektive koja uključuje opšte principe slobode, jednakosti i solidarnosti iz specifičnijih društvenih ili međuljudskih očekivanja, normi ili zakona. Dakle, svaka faza predstavlja kvalitativnu razliku u načinu na koji osoba percipira sebe i svoju okolinu u odnosu na pitanja socijalne pravde i etičkog odlučivanja (Richardson, 1998). Viši nivoi moralnog rasuđivanja predviđaju odgovarajuće više nivoe moralne akcije (Thoma \& Rest, 1986), a viši nivoi moralnog razvoja su pozitivno povezani sa višim nivoima empatije i altruizma kao primarnim moralnim emocijama. Po teoriji Kolberga (Kolhberg, 1984, prema Мурџева-Шкариќ, 2009), rani adolescent moralno rasuđuje na drugom, konvencionalnom nivou, razumevajući moralnost kao način da se održe harmonični odnosi uzimajući u obzir kontekst pravila i normi. Zakon je imperativ koji se mora poštovati. Kasnije, kada adolescent dostigne stadijum formalnih operacija u kognitivnom razvoju, on u moralnom razvoju prelazi u postkonvencionalni nivo i donosi moralni sud na osnovu društvenih ugovora, individulanih prava i privilegija ili, ređe na osnovu univerzalnih, moralnih principa.

Teorijski pristup Linda i saradnika (1985) predstavlja zapravo sintezu kognitivnog i afektivnog aspekta moralnosti, tj. atribute istog ponašanja, i nikako nisu dva ontološki razdvojena entiteta. Dakle, kognitivni aspekt, koji se odnosi na strukturu prosuđivačkog postupka, uvek mora biti određen u odnosu na moralni sadržaj i da se odvija kroz stadijume i nepromenljivo. Ipak empirijski dokazi (Eisenberg et al., 2005) pokazuju da stupnjevi koje osoba postiže u svom razvoju, nisu potpun, a nisu ni pouzdan dokaz da će se konkretna osoba u konkretnoj situaciji poneti moralno.

Značaj primarnih agensa socijalizacije u razvoju moralnog mišljenja potvrđen je kroz brojna istraživanja. Tako, istraživanja Vokera i saradnika (Walker et al., 2000) ispituju verbalnu interakciju sa roditeljima i vršnjacima, ego sposobnosti i nivo moralnog rasuđivanja pojedinaca od kraja detinjstva do srednje adolescencije. Tom prilikom utvrđeno je da interakcija sa vršnjacima i roditeljima utiče, ali različito na različitim nivoima. Visoko podsticajni kontekst koji karakteriše kvalitetna interakcija omogućavao je viši nivo moralnog mišljenja.

Imajući u vidu da smo ovim istraživanjem želeli da utvrdimo kojim se vaspitnim postupcima hraniteljske porodice koriste u podsticanju moralnog ponašanja dece o kojoj se staraju, smatramo potrebnim da definišemo vaspitne postupke koje hranitelji primenjuju u podsticanju moralnog razvoja dece o kojoj se staraju. U najširem smislu metoda podsticanja je vaspitni metod ,kojim kod vaspitanika delujemo sa ciljem da započne, istraje ili dovrši određenu aktivnost" (Suzić, 2005, 1) i njen značaj ogleda se u ,pozitivnom uticanju na volju i svest, na razvijanje dobrih pobuda i motiva što doprinosi bržem i efikasnijem donošenju odluka za akciju i odluka koje su u vezi sa postavljenim ciljem“ (Pedagoška enciklopedija 2, 1989, 205). Na 
konkretnom nivou, metoda podsticanja je aktivizirajuća metoda koja razvija želju za aktivnošću i afirmacijom, tj. podrazumeva pedagoški optimizam, veru u mogućnost razvijanja ličnosti što je u upitniku koji je primenjen opracionalizovano preko skale koja nosi naziv humanstički pristup u vaspitanju. Modelovanje ponašanja, primena sistema nagrada i kazni, pozitivna tj. negativna potkrepljenja u podsticanju moralnog razvoja dece na hraniteljstvu u upitniku su operacionalizovani preko skale definisane kao bihejvioralni pristup. Na kraju preko skale jednakost tretmana želeli smo da utvrdimo da li se hranitelji koriste istim vaspitnim postupcima u podsticanju moralnog razvoja kod biološke i dece na hraniteljstvu.

\section{Ko su deca bez roditeljskog staranja?}

Porodica kao bio-psiho-socijalna zajednica od davnina pa sve do savremenog doba predstavlja kontekst $u$ kome dete stiče prva životna iskustva i koja obezbeđuje razvoj svih aspekata detetove ličnosti, fizički, kognitivni, socijalni, emocionalni i moralni. Međutim, postoji jedan broj dece koja privremeno ili trajno iz različitih razloga ostaju bez neposredne roditeljske brige. Dalju brigu o njima preuzima država primenjujući neki od zakonom predviđenih oblika zaštite kao što je smeštaj u ustanovu socijalne zaštite, porodični smeštaj u hraniteljskoj porodici i usvojenje (Lukić-Havelka, Seratlić i sar., 2002).

Deca (privremeno ili trajno) lišena roditeljskog staranja predstavljaju krajnje specifičnu, vulnerabilnu grupu dece čiji je normalan tok razvoja prekinut razlozima koji se duž kontinuuma kreću od onih koregibilnih do onih koji ostavljaju trajne posledice po detetov psiho-fizički razvoj. To mogu biti neadekvatna realizacija vaspitne funkcije roditelja, socijalno-ekonomska ugroženost roditelja, zdravstvena sprečenost roditelja, disfunkcionalni porodični odnosi, smrt roditelja, nepoznati ili nestali roditelji (Grujić, 2005).

Primarni uticaj na današnji položaj dece bez roditeljskog staranja ima Konvencija Ujedinjenih nacija o pravima deteta (1989) koja se posebno bavi decom, njihovim potrebama i dobrobiti. Sadržaj Konvencije odgovara savremenom shvatanju deteta aposotrofirajući u članu 20 značaj odrastanja dece bez roditeljskog staranja $\mathrm{u}$ alternativnim porodičnim uslovima ili ustanovama. U skladu sa sadržajem Konvencije, u Porodičnom zakonu (2005, čl. 113, st. 3) naše zemlje pod detetom bez roditeljskog staranja smatra se: „dete koje nema žive roditelje, dete čiji su roditelji nepoznati ili je nepoznato njihovo boravište, dete čiji su roditelji potpuno lišeni roditeljskog prava odnosno poslovne sposobnosti, dete čiji roditelji još nisu stekli poslovnu sposobnost, dete čiji su roditelji lišeni prava na čuvanje i podizanje odnosno vaspitavanje deteta i dete čiji se roditelji ne staraju o detetu ili se staraju o detetu na neodgovarajući način".

S obzirom na predmet istraživanja, u daljem tekstu ćemo prikazati institut porodičnog smeštaja u hraniteljskoj porodici kao dominantan oblik zaštite dece koja su privemeno ili trajno ostala bez roditeljskog staranja. 


\section{Porodični smeštaj dece u hraniteljskim porodicama kao oblik zaštite dece bez roditeljskog staranja}

Porodični smeštaj u hraniteljskoj porodici predstavlja alternativni, društveno organizovani oblik zbrinjavanja dece koja su privremeno ili trajno lišena roditeljskog i porodičnog staranja i čiji je razvoj ometen prilikama u sopstvenoj porodici. Primarni cilj ovog oblika zaštite jeste staranje o ličnosti deteta, obezbeđivanje kontinuiteta i stabilnosti detetu koje iz različitih razloga privremeno ili u dužem vremenskom periodu ne može da živi sa svojim roditeljima ili srodnicima.

Hraniteljska porodica je posebno odabrana, motivsana i pripremljena porodica kojoj se na brigu, staranje i vaspitanje uz novčanu nadoknadu poverava dete bez roditeljskog staranja (Vidanović, 2008). Zasnivanjem hraniteljstva uspostavlja se odnos između deteta $\mathrm{i}$ hranitelja koji odgovara odnosu roditelj-dete. Hranitelji preuzimaju neposrednu brigu o detetu i imaju dužnost da se staraju o njegovom zdravlju, razvoju, vaspitanju i obrazovanju, a sa ciljem njegovog osposobljavanja za samostalan život (Pravilnik o hraniteljstvu, 2008). Pored osnovne uloge da zadovolji razvojne potrebe detetu i obezbedi adekvatne uslove za razvoj dečije ličnosti, hraniteljska porodica, pre svega, treba da pruži priliku detetu da porodični život zasnovan na kvalitetima, kao što su ljubav, razumevanje i empatija, doživi na pozitivan način, kao korektivno iskustvo vezivanja koje će mu pomoći da prevlada socijalne i emocionalne teškoće iz prošlosti s obzirom izloženost traumatičnim iskustvima, zanemarivanju i zlostavljanju u biološkoj porodici.

Iz svega napred navedenog, proizilazi kompleksnost hraniteljske uloge koja zahteva određena znanja i veštine za uspešno odgajanje i kompenzaciju svih nedostataka i negativnih iskustava dece. S obzirom na to da hraniteljske porodice predstavljaju jednu vrlo heterogenu grupu u pogledu nacionalnosti, socioekonomskog statusa, stepena obrazovanja, porodične strukture, religije, veroispovesti, pa i motivacije za bavljenje hraniteljstvom, a u cilju uspešnog odgovora na potrebe dece u sistemu socijalne zaštite, važno je da se kroz program pripreme upoznaju sa očekivanjima od hraniteljske uloge, specifičnostima hraniteljstva i razlikama u odnosu na biološko roditeljstvo, a naročito sa važnošću svoje uloge u moralnom formiranju dece o kojoj se staraju. Iako je hraniteljstvo kao oblik zaštite privremen i kratkoračan, činjenica je da mnoga deca ostaju sa svojim hraniteljima po više godina, čak i do okončanja školovanja i postaju važni članovi njihovih porodica.

Dakle, aktuelni porodični aranžman je primarni faktor koji utiče na oblikovanje ličnosti deteta i stvara šemu osnovnih moralnih pojmova, socijalizuje dete, prenosi šeme ponašanja koje su primerene određenim ulogama odraslih posredstvom ponašanja i životnih situacija (Đorđević, 2012). Mnogo snažnije od neposrednog moralnog vođenja jesu one neizrečene pretpostavke i premise na kojima se odvija život i režim u porodici. 


\section{Metodološki pristup istraživanju}

Istraživanje je imalo za cilj utvrđivanje vaspitnih faktora u hraniteljskim porodicama i moralnog razvoja dece na hraniteljstvu predadolescentnog i adolescentnog uzrasta. Za potrebe ovog istraživanja korišćena je sistematska neeksperimentalna metoda, tehnika anketiranja, a kao instrumenti istraživanja korišćeni su test moralnog rasuđivanja (Moral Judgement Test, konstruisan 1975-77, prema Lind, 2008) koji sadrži dve moralne dileme i instrument konstruisan za potrebe ovog istraživanja kojim su prikupljeni podaci o vaspitnim postupcima koju hranitelji primenjuju u podsticaju moralnog razvoja biološke i dece na hraniteljstvu. Istraživanje je sprovedeno tokom septembra meseca tekuće 2019. U istraživanju je učestvovalo 59 hranitelja, skoro ujednačenih po polu (28 muškaraca i 31 žena) i 59 dece uzrasta od 9 do 17 godina zaštićene ovim oblikom zaštite Nišavskog okruga.

\section{Rezultati istraživanja}

Sagledavajući kompleksnost problema kojim se bavimo, postavljeni predmet i cilj istraživanja primenjeni su postupci deskriptivne statistike i statistike zaključivanja. Najpre su za utvrđivanje stepena izraženosti osnovnih varijabli istraživanja korišćenje tehnike deskriptivne statistike - aritmetička sredina i standardna devijacija, frekvencija i procenat, a zatim su se u cilju utvrđivanja povezanosti osnovnih varijabli istraživanja primenile korelacione tehnike (Pirsonov koeficijent korelacije). Za ispitivanje razlike primenjena je statistička tehnika t-test ili ANOVA, a za ispitivanje prediktivne moći modela primenjena je regresiona analiza ili njihovi neparametrijski pandani, ukoliko osobine podataka to zahtevaju.

Tabela 1. Prikaz deskriptivnih mera ispitivanih koncepata

\begin{tabular}{|c|c|c|c|c|c|c|c|c|c|}
\hline & $\begin{array}{l}\text { Teorijski } \\
\text { Min }\end{array}$ & $\begin{array}{l}\text { Teorijski } \\
\text { Max }\end{array}$ & $\begin{array}{l}\text { Empirijski } \\
\text { Min }\end{array}$ & $\begin{array}{l}\text { Emprijski } \\
\text { Max }\end{array}$ & $\begin{array}{l}\text { Teorijska } \\
\text { AS }\end{array}$ & $\begin{array}{l}\text { Empirijska } \\
\text { AS }\end{array}$ & SD & $\alpha$ & $\begin{array}{l}\text { Sharpio- } \\
\text { Wilki test } \\
\text { normalnost } \\
\text { (p) }\end{array}$ \\
\hline TRETMAN & 1 & 5 & 2.80 & 5.00 & 2.5 & 4.2034 & .54138 & .723 & .000 \\
\hline $\begin{array}{l}\text { BIHEJVIORALNI } \\
\text { PRISTUP }\end{array}$ & 1 & 5 & 2.40 & 5.00 & 2.5 & 4.0407 & .52625 & .797 & .010 \\
\hline $\begin{array}{l}\text { HUMANISTIČKI } \\
\text { PRISTUP }\end{array}$ & 1 & 5 & 2.60 & 5.00 & 2.5 & 4.3356 & .51920 & .803 & .000 \\
\hline Situacija 1 - hranitelj & -3 & 3 & -3 & 3 & 0 & -1.3390 & 2.18624 & & .000 \\
\hline Situacija 2 -hranitelj & -3 & 3 & -3 & 3 & 0 & -2.3051 & 1.73458 & & .000 \\
\hline $\begin{array}{l}\text { Prekonvencionalni } \\
\text { rani - hranitelj }\end{array}$ & -4 & 4 & -3.00 & 4.00 & & -.1949 & 1.41655 & & .294 \\
\hline $\begin{array}{l}\text { Prekonvencionalni } \\
\text { kasni - hranitelj }\end{array}$ & -4 & 4 & -2.50 & 4.00 & & .2373 & 1.31751 & & .001 \\
\hline $\begin{array}{l}\text { Konvencionalni rani } \\
\text { - hranitelj }\end{array}$ & -4 & 4 & -3.00 & 4.00 & & .3941 & 1.33762 & & .080 \\
\hline $\begin{array}{l}\text { Konvencionalni kasni } \\
\text { - hranitelj }\end{array}$ & -4 & 4 & -1.75 & 4.00 & & .9746 & 1.16680 & & .157 \\
\hline $\begin{array}{l}\text { Postkonvencionalni } \\
\text { rani - hranitelj }\end{array}$ & -4 & 4 & -2.25 & 4.00 & & .1271 & 1.34419 & & .001 \\
\hline $\begin{array}{l}\text { Postkonvencionalni } \\
\text { kasni - hranitelj }\end{array}$ & -4 & 4 & -2.75 & 4.00 & & -.0127 & 1.36017 & & .000 \\
\hline
\end{tabular}




\begin{tabular}{|c|c|c|c|c|c|c|c|c|}
\hline Situacija 1 - štićenik & -3 & 3 & -3 & 3 & 0 & -1.5932 & 1.83940 & .000 \\
\hline Situacija 2 - štićenik & -3 & 3 & -3 & 3 & 0 & -1.8136 & 2.35968 & .000 \\
\hline $\begin{array}{l}\text { Prekonvencionalni } \\
\text { rani -štićenik }\end{array}$ & -4 & 4 & -3.75 & 2.00 & & -.5000 & 1.28234 & .079 \\
\hline $\begin{array}{l}\text { Prekonvencionalni } \\
\text { kasni - štićenik }\end{array}$ & -4 & 4 & -4.00 & 3.50 & & -.0720 & 1.39353 & .073 \\
\hline $\begin{array}{l}\text { Konvencionalni rani } \\
\text { - štićenik }\end{array}$ & -4 & 4 & -4.00 & 2.75 & & -.1144 & 1.59763 & .049 \\
\hline $\begin{array}{l}\text { Konvencionalni kasni } \\
\text { - štićenik }\end{array}$ & -4 & 4 & -4.00 & 3.75 & & .7034 & 1.34347 & .038 \\
\hline $\begin{array}{l}\text { Postkonvencionalni } \\
\text { rani - štićenik }\end{array}$ & -4 & 4 & -4.00 & 4.00 & & .0975 & 1.47830 & .024 \\
\hline $\begin{array}{l}\text { Postkonvencionalni } \\
\text { kasni - štićenik }\end{array}$ & -4 & 4 & -4.00 & 4.00 & & -.5720 & 1.50362 & .067 \\
\hline
\end{tabular}

Tabela br. 1 pokazuje distribuciji odgovora hranitelja (gornji deo tabele) i dece (donji deo tabele) na ispitivanim skalama. Podaci dobijeni analizom kazuju da hranitelji jednako pristupaju svojoj biološkoj i deci na hraniteljstvu (empirijska AS na skali tretman, veća je od teorijskog proseka na toj skali i iznosi 4.2034), da u procesu vaspitanja visoko vrednuju principe bihejvioralnog pristupa (empirijska AS veća je od teorijske AS i iznosi 4.0407) i principe humanističkog pristupa (empirijska AS veća je od teorijske AS i iznosi 4.3356). Standardne devijacije na ove tri skale su niske što govori o usklađenosti odgovora svih hranitelja. Pouzdanost skala ispitivana Krombah alfa koeficijentom konzistentnosti je zaodovoljavajuća $(\alpha>0.7)$.

Opisane reakcije u dve situacije procenjivali su i hranitelji i deca na hraniteljstvu i na osnovu empirijske aritmetičke sredine može se reći da su i hranitelji i deca na hraniteljstvu u proseku procenili kao neadekvatne. Međutim, standardna devijacija odgovora govori da se odgovori ispitanika međusobno razlikuju, odnosno da ima ispitanika koju opisane reakcije samtraju adekvatnim, na šta ukazuje i empirijski maksimum. Kako skala moralnog rasuđivanja predstavlja skalu gde najveći skor stadijuma predstavlja stadijum na kome se ispitanik nalazi, na osnovu empirijske AS može se zaključiti da se i hranitelji (empirijska AS za kasni konvencionalni stadijum iznosi 0.9746 ) i deca (emirijska AS za kasni konvencionalni stadijum iznosi, 0.7034) nalaze na konvencionalnom kasnom stadijumu. Poslednja kolona predstavlja stastističku značajnost poređenja distribucije odgovora ispitanika ovog istraživanja sa normalnom distribucijom i govori o tome da se distribucije ovde dobijenih odgovora statistički značajno razlikuju od normalne, te će primenjene tehnike u narednim koracima biti neparametrijske.

Tabela 2. Prikaz povezanosti stupnjeva moralnog razvoja hranitelja i dece

\begin{tabular}{|c|c|c|c|c|c|c|c|}
\hline & & $\begin{array}{l}\text { Prekonven- } \\
\text { cionalni rani } \\
\text { - dete }\end{array}$ & $\begin{array}{l}\text { Prekonvenci- } \\
\text { onalni kasni } \\
\text { - dete }\end{array}$ & $\begin{array}{l}\text { Konvenci- } \\
\text { onalni rani } \\
\text { - dete }\end{array}$ & $\begin{array}{l}\text { Konvencio- } \\
\text { nalni kasni } \\
\text { - dete }\end{array}$ & $\begin{array}{l}\text { Postkonvencio- } \\
\text { nalni rani - dete }\end{array}$ & $\begin{array}{l}\text { Postkonven- } \\
\text { cionalni kasni } \\
\text { - dete }\end{array}$ \\
\hline \multirow{2}{*}{$\begin{array}{l}\text { Prekonvencionalni } \\
\text { rani - hranitelj }\end{array}$} & $\begin{array}{l}\text { Koeficijent } \\
\text { korelacije }\end{array}$ & -.004 & .213 & .130 & .219 & .028 & -.086 \\
\hline & $\mathrm{p}$ & .977 & .106 & .325 & .096 & .833 & .515 \\
\hline \multirow{2}{*}{$\begin{array}{l}\text { Prekonvencionalni } \\
\text { kasni - hranitelj }\end{array}$} & $\begin{array}{l}\text { Koeficijent } \\
\text { korelacije }\end{array}$ & .107 & $.326^{*}$ & $.304^{*}$ & .146 & .024 & .013 \\
\hline & $\mathrm{p}$ & .422 & .012 & .019 & .270 & .854 & .922 \\
\hline \multirow{2}{*}{$\begin{array}{l}\text { Konvencionalni } \\
\text { rani - hranitelj }\end{array}$} & $\begin{array}{l}\text { Koeficijent } \\
\text { korelacije }\end{array}$ & -.109 & .203 & $.289^{*}$ & .005 & -.087 & -.133 \\
\hline & $\mathrm{p}$ & .410 & .123 & .026 & .967 & .512 & .314 \\
\hline
\end{tabular}




\begin{tabular}{|c|c|c|c|c|c|c|c|}
\hline \multirow{2}{*}{$\begin{array}{l}\text { Konvencionalni } \\
\text { kasni - hranitelj }\end{array}$} & $\begin{array}{l}\text { Koeficijent } \\
\text { korelacije }\end{array}$ & .123 & .172 & $.276^{*}$ & $.346^{* * *}$ & .172 & -.042 \\
\hline & $\mathrm{p}$ & .353 & .192 & .034 & .007 & .193 & .749 \\
\hline \multirow{2}{*}{$\begin{array}{l}\text { Postkonvencionalni } \\
\text { rani - hranitelj }\end{array}$} & $\begin{array}{l}\text { Koeficijent } \\
\text { korelacije }\end{array}$ & $.275^{*}$ & .156 & .189 & .168 & .229 & .112 \\
\hline & $\mathrm{p}$ & .035 & .239 & .153 & .203 & .082 & .398 \\
\hline \multirow{2}{*}{$\begin{array}{l}\text { Postkonvencionalni } \\
\text { kasni - hranitelj }\end{array}$} & $\begin{array}{l}\text { Koeficijent } \\
\text { korelacije }\end{array}$ & .076 & .100 & .132 & -.086 & -.061 & $.282^{*}$ \\
\hline & $\mathrm{p}$ & .565 & .453 & .321 & .518 & .649 & .031 \\
\hline
\end{tabular}

Statistički značajne pozitivne korelacije, srednjeg intenziteta, na nivou 0.01 zabeležene su između konvencionalnog kasnog stadijuma hranitelja i konvencionalnog kasnog stadijuma deteta. Statistički značajne pozitivne korelacije, srednjeg inzeziteta, na nivou 0.05 zabeležene su između postkonvencionalnog ranog stadijuma hranitelja i prekonvencionalnog ranog stadijuma deteta; konvencionalnog kasnog stadijuma hranitelja i konvencionalnog ranog stadijuma deteta i postkonvencionalnog kasnog stadijuma hranitelja i postkonvencionalnog kasnog stadijuma deteta. Ove pozitivne korelacije uslovno rečeno govore o uticaju nivoa razvoja moralnog stadijuma hranitelja na nivo razvoja moralnog stadijuma deteta. Dakle, što je određeni stadijum više, odnosno manje razvijen kod hranitelja, on je manje (više) razvijen i kod deteta. Ovaj podatak čini delimično potvrđenu prvu hipotezu istraživanja.

Tabela 3. Prikaz povezanosti načina podsticanja moralnog ponašanja (jednakost tretmana, bihejvioralni pristup, humanistički pristup) i nivoa moralnog razvoja deteta

\begin{tabular}{|c|c|c|c|c|c|c|c|}
\hline & & $\begin{array}{l}\text { Prekonven- } \\
\text { cionalni rani } \\
\text { - dete }\end{array}$ & $\begin{array}{l}\text { Prekonvenci- } \\
\text { onalni kasni } \\
\text { - dete }\end{array}$ & $\begin{array}{l}\text { Konvenci- } \\
\text { onalni rani } \\
\text { - dete }\end{array}$ & $\begin{array}{l}\text { Konvencio- } \\
\text { nalni kasni } \\
\text { - dete }\end{array}$ & $\begin{array}{l}\text { Postkonvencio- } \\
\text { nalni rani - dete }\end{array}$ & $\begin{array}{l}\text { Postkonvencional- } \\
\text { ni kasni - dete }\end{array}$ \\
\hline \multirow{2}{*}{ TRETMAN } & $\begin{array}{l}\text { Koeficijent } \\
\text { korelacije }\end{array}$ & $-.266^{*}$ & -.088 & -.178 & -.051 & $-.325^{*}$ & $-.398^{*}$ \\
\hline & $\mathrm{p}$ & .042 & .508 & .177 & .702 & .012 & .002 \\
\hline \multirow{2}{*}{$\begin{array}{l}\text { BIHEJV. } \\
\text { PRISTUP }\end{array}$} & $\begin{array}{l}\text { Koeficijent } \\
\text { korelacije }\end{array}$ & $-.272^{*}$ & -.134 & $-.277^{*}$ & -.136 & -.139 & -.273 \\
\hline & $\mathrm{p}$ & .037 & .311 & .033 & .305 & .293 & .036 \\
\hline \multirow{2}{*}{$\begin{array}{l}\text { HUMANISTIČKI } \\
\text { PRISTUP }\end{array}$} & $\begin{array}{l}\text { Koeficijent } \\
\text { korelacije }\end{array}$ & -.110 & $.259^{*}$ & $.346^{* x}$ & .159 & .125 & -.008 \\
\hline & $\mathrm{p}$ & .405 & .048 & .007 & .228 & .347 & .955 \\
\hline
\end{tabular}

Statistički značajne pozitivne korelacije, srednjeg intenziteta, na nivou 0.01 zabeležene su između konvencionalnog ranog stadijuma deteta i humanističkog pristupa u vaspitanju dece od strane hranitelja; postkonvenvionalnog kasnog stadijuma deteta i jednakosti tretmana. Statistički značajne pozitivne korelacije, srednjeg inzeziteta, na nivou 0.05 zabeležene su između prekonvecionalnog kasnog stadijuma deteta i humanističkog pristupa dok su statistički značajne negativne korelacije, srednjeg inzeziteta, na nivou 0.05 zabeležene između prekonvencionalnog ranog stadijuma deteta i tretmana i bihejvioralnog pristupa; konvencionalnog ranog stadijuma deteta i bihejvioralnog pristupa i postkonvenvionalni ranog i kasnog stadijuma deteta $\mathrm{i}$ jednakosti tretmana. 


\section{Diskusija rezultata}

U ovom radu nastojali smo da utvrdimo odnos vaspitnih faktora u hraniteljskim porodicama i moralnog razvoja dece na hraniteljstvu. Znajući da je moralni razvoj dece i mladih uslovljen multufaktorskom etiologijom, a imajući u vidu specifičnost i kompleksnost razvojnog i porodičnog statusa dece koja su činila uzorak u našem istraživanju kao i prirodu porodičnog smeštaja dece $u$ hraniteljskim porodicama pretpostavili smo da postoji statistički značajna povezanost stadijuma moralnog rasuđivanja deteta koje je na hraniteljstvu sa stadijumom moralnog rasuđivanja hranitelja i da postoji statistički značajna povezanost načina podsticanja moralnog razvoja i stadijuma moralnog rasuđivanja dece u hraniteljskim porodicama.

U distribuciji odgovora hranitelja i dece na ispitivanim skalama dobili smo da se i hranitelji i deca nalaze na konvencionalnom kasnom stadijumu. S obzirom na uzrast dece koji je obuhvaćen našim uzorkom (9-17 godina), analogno stadijumu kognitivnog razvoja dece (stadijum formalnih operacija), rezultati su pokazali da se deca nalaze na očekivanom konvencionalnom kasnom stadijumu moralnog razvoja kojim se podržava društveni red i dobrobit institucije, društva i grupe. Očekivali smo da će rezultati pokazati viši nivo moralnog rezonovanja kod hranitelja s obzirom da su ranija istraživanja (Rest, 1974; Thoma \& Rest, 1999; Walker \& Taylor, 1991) pokazala da sociodemografski faktori kao što su godine starosti utiču na viši nivo moralnog rasuđivanja što je značajan prediktor koji će moralni razvoj dece vući ka narednoj zoni razvoja.

Prva hipoteza kojom se pretpostavlja da postoji statistički značajna povezanost stadijuma moralnog rasuđivanja dece na hraniteljstvu sa stadijumom moralnog rasuđivanja hranitelja je delimično potvrđena jer dobijeni podaci pokazuju da postoje pozitivne korelacije srednjeg intenziteta samo na pojedinim skalama, $i$ to na nivou 0.01 konvencionalnog kasnog stadijuma hranitelja i konvencionalnog kasnog stadijuma deteta, a na nivou statističke značajnosti 0,05 postkonvencionalnog ranog stadijuma hranitelja i prekonvencionalnog ranog stadijuma deteta, konvencionalnog kasnog stadijuma hranitelja i konvencionalnog ranog stadijuma deteta i postkonvencionalnog kasnog stadijuma hranitelja i postkonvencionalnog kasnog stadijuma deteta. Može se reći da pozitivne korelacije govore o uticaju nivoa razvoja moralnog stadijuma hranitelja na nivo razvoja moralnog stadijuma deteta, tj. da se stadijum moralnog razvoja hranitelja neposredno odražava na stadijum moralnog razvoja deteta na hraniteljstvu. Dobijeni podaci potvrđuju važnost i snagu učenja po modelu koje je naročito apostrofirala teorija socijalnog učenja (Jevtić, 2012). Imajući u vidu da deca koja se nalaze na smeštaju u hraniteljskim porodicama lišena sigurne baze u biološkoj porodici, svoju potrebu za identifikacijiom, tj. za naklnošću i ljubavlju, nalaze $u$ hraniteljima kao izvorima pozitivnih i negativnih potkrepljenja. U skladu sa teorijskim postulatima, možemo reći da dobijeni rezultati ukazuju na to da aktuelni stadijum moralnog razvoja dece je posledica kontinuiranog učenja i oblikovanja ponašanja, a na osnovu moralnog rezonovanja i ponašanja hranitelja.

Druga hipoteza kojom smo pretpostavili da postoji statistički značajna povezanost načina podsticanja moralnog razvoja (jednakost tretmana biološke i dece na 
hraniteljstvu, bihejvioralni pristup u vaspitanju, humanistički pristup u vaspitanju) i stadijuma moralnog rasuđivanja dece u hraniteljskim porodicama je takođe delimično potvrđena jer dobijeni podaci pokazuju pozitivne korelacije metoda podsticanja samo na pojedinim stadijumima moralnog rasuđivanja i to konvencionalnog ranog stadijuma deteta i humanističkog pristupa u vaspitanju dece od strane hranitelja, postkonvenvionalnog kasnog stadijuma deteta i jednakosti tretmana kao i prekonvecionalnog kasnog stadijuma deteta i humanističkog pristupa. Naime, pokazalo se da humanistički pristup hranitelja pozitivno utiče na razvoj konvencionalnog ranog stadijuma kod dece, tj. na razvoj ematije i brige za druge, razvoju odanosti i motivaciji za pridržavanjem pravila i ispunjavanjem očekivanja.

Dobijeni rezultati nas navode na zaključak da jednakost tretmana koju hranitelji primenjuju u odnosu na vaspitanje svoje i dece na hraniteljstvu pozitivno korelira sa postkonvecinonalnim ranim stadijumom deteta koji podrazumeva kritiku postojećeg zakona i institucionalne prakse kada se ne štite i ne unapređuju osnovna ljudska prava. Zapravo, hranitelji svojim jednakim tretmanom kod dece neguju poštovanje društvenog reda, ali ne nužno i svako društveno pravilo ili dogovor. Takođe, humanistički pristup hranitelja u odnosu prema detetu se pozitivno reflektuje i na individualnu instrumentalnu moralnost koja podrazumeva ostvarivanje ličnih, ali i interesa drugih ljudi. Međutim, korelacije negativnog smera zabeležene su između prekonvencionalnog ranog stadijuma deteta i tretmana i bihejvioralnog pristupa; konvencionalnog ranog stadijuma deteta $\mathrm{i}$ bihejvioralnog pristupa i postkonvenvionalni ranog i kasnog stadijuma deteta i jednakosti tretmana. Negativne korelacije na dobijenim nivoima navode nas na objašnjenje da deca zaštićena porodičnim smeštajem u hraniteljskoj porodici ipak ne opažaju da se njihovi hranitelji jednako odnose prema njima i prema svojoj biološkoj deci. Čak i tamo gde se očekuje pozitivan smer korelacije u skladu sa napred nevedenim teorijskim implikacijama (Đorđević, 2012) on ne postoji; na stadijumu gde se moralonost nagradom i kaznom moduliše kao što je to kod pretkonvencionalnog stadijuma negativnog je smera, a to znači da što je princip potkrepljenja intenzivniji, skor na ovom stadijumu je niži. Takođe, pokazalo se da odgovori hranitelja u primeni istih vaspitnih principa u podsticanju moralnog razvoja svoje i biološke dece u podsticanju moralnog razvoja dovodi do nižeg skora na postkonvencionalnim stadijumima.

\section{Zaključna razmatranja}

Moralni razvoj i moralno vaspitanje je jedna u nizu značajnih oblasti kojima se socijalna pedagogija kao naučna disciplina bavi. Sagledavajući svu složenost i kompleksnost moralnog razvoja dece i mladih, sa jedne strane, i jako mali broj istraživanja o hraniteljskim porodicama i deci bez roditeljskog staranja koja su zaštićena ovim oblikom zaštite, sa druge strane, ovim radom smo želeli utvrditi kako vaspitni faktori podstiču moralni razvoj dece koja su zaštićena porodičnim smeštajem u hraniteljskoim porodicama, želeći time da damo svojevrstan naučni doprinos ovoj problematici. 
Na temelju sprovedenog istraživanja pokazalo se da se i hranitelji i deca nalaze na konvencionalnom kasnom stadijumu moralnog razvoja što nije u potpunosti sa našim očekivanjima s obzirom da smo očekivali da će rezultati pokazati viši nivo moralnog rezonovanja kod hranitelja imajući u vidu godine starosti, transgeneracijske modele i obrasce ponašanja, motivaciju za bavljenje hraniteljstvom i sl.

Ispitujući povezanost stadijuma moralnog rasuđivanja deteta koje je na hraniteljstvu sa stadijumom moralnog rasuđivanja hranitelja pokazalo se da postoje pozitivne korelacije pojedinih stupnjeva moralnog razvoja hranitelja i dece dok u drugim takva povezanost nije pronađena. Što se tiče načina podsticanja moralnog ponašanja operacionalizovanog kroz jednakost tretmana biološke i dece na hraniteljstvu, bihejvioralnog i humanističkog pristupa u vaspitanju kao značajnog prediktora stadijuma moralnog rasuđivanja dece na hraniteljstvu pokazalo se da postoji i pozitivna i negativna povezanost pojedinih nivoa moralnog razvoja deteta i pristupa u vaspitanju dok na drugim nivoima povezanosti pozitivnog i negativnog smera nisu pronađene. Dobijeni rezultati nas navode na zaključak da u podsticanju moralnog razvoja dece ne postoji dosledan i strukturisan vaspitni uticaj već da je on uslovljen brojnim individalnim, porodičnim i sredinskim faktorima što svedoči u prilog velikoj heterogenosti mreže hraniteljskih porodica.

Rezultati našeg istraživanja nametnuli su nekoliko pedagoških implikacija: promena pristupa u postupku procene potencijalnih hraniteljskih porodica; kontinuirana stručna podrška profesionalcima socijalne zaštite iz oblasti moralnog razvoja dece; implementacija programa namenjenih hraniteljskim porodicama o važnosti i značaju razvoja i podsticanja moralnog razvoja dece u njhovim porodicama.

\section{Literatura}

Antonijević, R. (2013). Opšta pedagogija. Beograd: Institut za pedagogiju i andragogiju.

Đorđević, J. (2012). Talentovani učenici:vrednosti i moralno vaspitanje. U Srpska akademija obrazovanja (17), 276-290.

Eisenberg, N., Cumberland, A., Guthrie, I. K., Murphy, B. C. and Shepard, S. A. (2005). Age changes in prosocial responding and moral reasoning in adolescence and early adulthood. Journal of Research on Adolescence (15), 235-260.

Grujić, D. (2005). Porodični smeštaj dece: više od roditeljstva. Beograd: Udruženje stručnih radnika socijalne zaštite Republike Srbije.

Jevtić, B. (2012). Pedagogija moralnosti. Niš: Filozofski fakultet.

Konvencija Ujedinjenih nacija o pravima deteta (1989). Beograd: Unicef.

Kohlberg, L. (1984) The Psychology of Moral Development: The Nature and Validity of Moral Stages. Vol. 2. Harpercollins College Div.

Lind, G., Sandberger, J., and Bargel, T. (1985). Moral Competence and Democratic Personality. In G. Lind, H. A. Hartmann, \& R. Wakenhut (Eds.), Moral development and the social environment. Studies in the philosophy and psychology of moral judgment and education (56-77). Chicago: Precedents Publishing Inc. 
Lind, G. (2008). The meaning and measurement of moral judgment competence. A dualaspect

model. In: Daniel Fasko, Jr. \& Wayne Willis, eds.: Contemporary philosophical and psycho-

logical perspectives on moral development and education, 185-220.

Lukić-Havelka, D., Seratlić, D., Plut, D., Mitić, M. i saradnici (2002). Deca bez roditeljskog staranja: Istraživanje funkcionisanja sistema socijalne zaštite dece bez roditeljskog staranja. Beograd: Institut za psihologiju

Markov, Z. (2010). Moralno ponašanje prema deci sa smetnjama u razvoju. Socijalna misao, 17(3), 141-154.

Miočinović, Lj. (2004). Moralni razvoj i moralno vaspitanje: kognitivno-razvojno shvatanje. Beograd: Institut za pedagoška istraživanja.

Мурџева-Шкариќ, О. (2009). Психологија на детството и на адолесценцијата. Развојна психологија 1. Скопје: Филозофски Факултет.

Pedagoška enciklopedija 2 (1989). Beograd: Zavod za udžbenike i nastavna sredstva.

Popović, B., Miočinović, Lj. (1977). Moralne vrednosti dece i mladih i njihov razvoj. Beograd: Prosveta.

Popović, V.B (1977). Moralni razvoj i moralno vaspitanje. Beograd: Prosveta.

Porodični zakon (2005). Službeni glasnik RS, br. 18/2005.

Pravilnik o hraniteljstvu (2008). Službeni glasnik RS, br. 36/2008.

Rest, J. R. (1974). Developmental psychology as a guide to value education: A review of „Kohlbergian“ programs. Review of Educational Research, 44, 241-259.

Rest, J. R. \& Thoma, S. J. (1986). Relation of moral judgment development to formal education. Developmental Psychology, 21, 709-714.

Richardson, B. (1998). Parenting attitudes and moral development of treatment foster parents: implications for training and supervision. Child \& Youth Care Forum, 27(6), 409-431.

Suzić, N. (2005). Motivacija podsticanjem u univerzitetskoj nastavi. [Elektronska verzija]. U

knjizi: D. Branković i saradnici: Inovacije u univerzitetskoj nastavi (139-171). Banja Luka: Filozofski fakultet.

Thoma, S. J., \& Rest, J. R. (1999). The relationship between moral decision making and patterns of consolidation and transition in moral judgment development. Developmental Psyhology, 35, 323-334.

Vidanović, I. (2008): Rečnik socijalnog rada. Beograd: Udruženje stručnih radnika socijalne zaštite Srbije.

Walker, L. J., Hennig, K. H., \& Krettenauer, T. (2000). Parent and peer contexts for children's moral reasoning development. Child Development, 71, 1033-1048.

Walker, L. J. \& Taylor, J. H. (1991a). Stage transitions in moral reasoning: A longitudinal study of developmental processes. Developmental Psychology, 27, 330-337. 


\title{
ENCOURAGING THE MORAL DEVELOPMENT OF CHILDREN PROTECTED BY RESIDENTIAL ACCOMMODATION IN FOSTER FAMILIES
}

\author{
Sanja Sretić \\ Center for social work „Sveti Sava“ Niš \\ University of Niš, Faculty of Philosophy, Department of Pedagogy (PhD student)
}

\begin{abstract}
In a time of perplexing interpersonal relations, transitional models, multiculturalism, questions and problems of moral development of children and youths are especially actualized because they question the existent social and moral values, methods and actions by which these values have been adopted. This research was conducted with the aim of determining the educational factors in foster families and the moral development of pre-adolescent and adolescent children in foster care. This paper used a systematic non-experimental method. The results of the research showed that both foster parents and children are at a conventional late stage of moral development. Positive direction correlations were obtained at individual stages in examining the relationship between the stage of moral reasoning of the child in foster care and the stage of moral reasoning of the foster parent. Additionally, the obtained correlations of positive and negative direction in determining the foster parent's educational actions in encouraging the moral development of children in placement show that there is no harmonization and structured upbringing influence in the field of fostering the moral development of children in foster families. Moreover, it is conditioned by numerous individual, family, and environmental factors, which testifies to the great heterogeneity of the network of foster families. Research findings imply the need for more professional support for foster families and professionals in encouraging the moral development of children without parental care.
\end{abstract}

Keywords: moral development, incentive method; children without parental care; foster family.

Sretić, S. (2019). Podsticanje moralnog razvoja dece zaštićene porodičnim smeštajem u hraniteljskim porodicama. Godišnjak za pedagogiju, 4(2), 73-85 